DOI: https://doi.org/10.47264/idea.lassij/4.2.29

Vol. 4, No. 2, (July-December 2020): 372-383

Research Article

URL: https://www.ideapublishers.org/index.php/lassij

\title{
Death as Martyrdom: A Psychoanalytical Study of Robert Bolt's a Man for all Seasons and T. S. Eliot's Murder in the Cathedral
}

\author{
Akbar Ali ${ }^{1}$, Abdul Hamid*2 ${ }^{2}$ Mashhood Ahmad ${ }^{3}$ \\ 1. Department of English, FATA University, Dara Adam Khel, Kohat, Pakistan. \\ 2. Department of English, University of Swat, Mingora, Pakistan. \\ 3. Department of English, Gomal University (Sub-campus), Tank, Pakistan.
}

Received: September 24, 2020

Published Online: December 31, 2020

\begin{abstract}
This paper focuses on the protagonists of two dramas A Man for All Seasons and Murder in the Cathedral to be studied through the critical prospective of psychoanalysis. The protagonists of the dramas meet their death at the end of the play and their death is appreciated as martyrdom by the readers of the plays without seeing critically their mottos behind their death. Challenging that, this paper varies in the stance that Beckett's death is a suicide rather than martyrdom, thus questioning the traits of the personalities of the protagonists and their mottos behind their deaths. Taking Freud's Psychoanalytical theory as a theoretical framework; Jung model of Psychoanalysis for conceptual terminologies and conducting close textual analysis, this study aims to conclude with references. The study is significant in a sense that it widens the dimensions of comparative studies of the modern literary works through contemporary critical theories. It also highlights the application of psychology in the literature in general and the English literature in specific.
\end{abstract}

Keywords: Psychoanalysis, Textual Analysis, Martyrdom, Protagonists, Id, Ego, Superego.

\section{Introduction}

Arts and literature provide a wide and rich area to psychoanalysis for its experimental implications. Psychoanalytical criticism is concerned with the quest for the subsequent analysis of the connection between the artists (creators, artificers) themselves and what they actually create i.e., novels, dramas, poetry, paintings, sculptures and music etc. In literature, it analyses the behavioural approach of the characters portrayed by the authors in their works. As a Literary theory, Psychoanalysis has been very effective in the in-depth analysis of the characters created in the literature. The projected characters are studied in relation to their creators and understanding about them leads to the universal phenomenon about human behaviours. Modern literary criticism uses Psychoanalysis to explore the behaviours of different characters projected as ideals of the author. The current paper is targeting the protagonists (Thomas More \& Thomas Beckett) of A Man for All Seasons and Murder in the Cathedral to be seen through Psychoanalytical theory for their social and religious mottos.

Skinner (1953) rites that the complex or obscure behaviours of the characters could be shown as the product of an individual history therefore this paper is also focused on the social and 
religious histories of the selected characters to logically submit the conclusion. This study has considered the historical background and religious tendency of the protagonists Thomas More and Thomas Beckett of the two dramas A Man for All Seasons and Murder in the Cathedral respectively to inquire the stance and achieve the desire objectives through close textual analysis while using Freud theory of Psychoanalysis.

Generally, both the protagonists of the selected dramas are glorified and applauded as martyrs however this paper holds a contradictory stance in the sense that the protagonist (Thomas Beckett) of Murder in the Cathedral has committed suicide to achieve his instinctive desires unlike the protagonist (Thomas More) of A Man for All Seasons who aimed at the rightness of the issue. Thus, this paper is purposed on the inquiry of meticulous motives of Thomas Beckett and spiritual motives of Thomas More towards death in the selected dramas respectively.

Clarifying further, firstly, this paper has brought into consideration that what are the personality traits of both the protagonists of the selected dramas that governs their actions and finally forced them both to die at the end of the dramas. Secondly, it has also highlighted that what are the impulsive components that are very influential in bringing both the characters to meet their respective death at the end of the plays. So, replying to the questions aroused, this article has to explain with references the difference between the tendencies of both the characters towards death generally and Christianity in particular. Along with that dismantling the protagonists' psyche through Freud's Psychoanalysis, to elucidate the components of their personalities that are impulsively taking part in ruling their social behaviours, religious beliefs and deadly, ends have been aimed in this paper.

This study makes sufficient contributions to the field of knowledge. Pedagogically, it will contribute to the opening of new avenue in research regarding psychoanalytical studies of different genres of literature, particularly dramas. It will bridge the gap for the students and researchers interested in comparative studies specifically psychoanalytical comparison. Methodologically, it will contribute to understanding the theory of psychoanalysis put forward by Sigmund Freud in specific and some others like Carl Gastov Jung and Jacques Laccan in general. It practices the application of Psychoanalysis in the field of contemporary literature and modern theory and criticism. This study is also helpful in bridging the relationship between

comparative literature and the exercise of the Psychoanalytical criticism. Socially, it helps the readers to understand the obscure behaviours of various individuals while studying psychologically. Moreover, this study equals sociology and literature on similar grounds.

This study aims to explore the personality traits of Thomas Beckett and Thomas More which has caused their death. The study also explores the absurdity and impulsive traits in the personality of the protagonists which has caused the death there in Murder in the Cathedral and A Man for All Seasons

\section{Literature Review}

Relating the study to the previous literature, certain reviews are overviewed to create a space for the current research analysis. Kareem (2011) who has looked at the main characters like Heathcliff, Catherine Earnshaw and Isabella Linton (characters) in Wuthering Heights from Freudian psychoanalytical point of view and has analysed critically their irrational behaviours. Not only the important two provinces (Conscious and Unconscious) of Psyche of the mentioned 
characters have been looked upon but the scholar has also concluded his discussion by summarizing that how the different mechanisms like Denial, Repression, Sublimation and Projection have further complexed the individual behaviours of the characters that resulted in the streamlining of their destiny at the end of the novel and influencing other minor characters of the novel too (Safran \& Hunter, 2020).

Similarly, Gholipour and Sanahmadi (2013) have brought the masterpiece The Great Gatsby under the same critical study. The eminent characters Tom Buchanan and Daisy Buchanan have been analyzed psychoanalytically and their apparent behaviours have been linked with the tripartite Id, ego and superego logically. The scholars have agreed at the point that both the characters are influentially controlled by their Id and a grudge has developed among the tripartite that has resulted in their conflicting personalities. They have further discussed and concluded that the apparent worldliness of Daisy is projection of the instinctive desires she has been controlled by and the sexual obsession of Tom is expression of the desires intrinsically developed and socially suppressed and channelized by ego and superego (Hossain, 2017).

Moreover, Marry (2013) has analysed The Devil and Miss Prym through Psychoanalytical theory in order to look at the personality of the protagonist, Miss Prym. Tripartite (Id, Ego and Superego) of mind has been focus of analysis throughout the critical work. Id, which is functioning on pleasure principle, forces Miss Prym to cross out the social and moral boundaries but, censored by ego and superego, she has made it parallel to the social demands and moral values. Studying closely personality of the protagonist, Marry (2013) argues that, in the developing stage of her sound personality, Miss Prym fails to defend the forces of the Id but then, as she gets over the destructive desires of the Id, ego helps her in balancing her personality. That is why temptation has been rejected and even Id has been coded with morality principle through ego and superego.

Developing further the related literature review, two Chinese scholars, Liu and Wang (2011) have collectively deemed at different literary works from psychological perspective. They have psychologically analyzed works like Hamlet by Shakespeare, Sons and Lovers by British writer D. H. Lawrence and two Chinese dramas Thunderstorm by Cao Yu and Dream of Red Mansions (a TV play). Protagonists of the given works have been psychoanalytically studied in their article under the Freudian Oedipus complex. Historical background of the Oedipus complex has been deemed at in the primary section of their article by referring to the Greek mythology Oedipus King. Comparing and arguing logically, they have studied the working of subconscious and unconscious of the protagonists Hamlet and Oedipus respectively while keeping Freudian Oedipus complex the base for their research. They have psychoanalytically approached Sons and Lovers in their article to highlight the oedipal complex behaviour of its protagonist Paul. Adversary in his attitude towards his father and incestuously caring about his mother, they have argued that the protagonist has been victim of Oedipus complex in his psychological development across the novel.

Analyzing psychoanalytically the protagonist of Thunderstorm, the scholars have argued that the protagonist is not only suffering from Oedipus complex, but he is also using defence mechanism of denial to avoid and express his unconscious past experience and incestuous desire towards his mother when he tries to expose his beloved. Applying Freudian Oedipus complex to Chinese TV play Dream of Red Mansions based on Chinese classical novel Dream of Red Chamber by Cheng Gao, the scholars have argued in the last part of their article that the protagonist of the drama Jia Baoyu is rebellious towards his father and cares his mother more 
than other women which results in the abnormal growth of his psychology. Concluding, all the above discussed works have been critically analysed through the lens of Freudian Oedipus complex to examine their psychological development in the works.

Mushtaq (2010) has investigated Marvel's poem To His Coy Mistress and analysed the passionate lover psychologically while applying Freudian tripartite model of human mind. In his research work, he has argued that across the poem psychical fight in lover's mind among id, ego and superego is going on and finally id conquers the other two provinces: ego and superego. Working in sequence, he has conducted close-textual analysis of the first two stanzas of Marvel's poem where, he has argued, that ego and superego have suppressed and dominated the instinctive desires of pleasure generated by id in the unconscious mind. Moving to its next and last stanza, the scholar has argued that it has conquered the other two and has satisfied its instinctive desire in general and sexual desire of the lover in particular. Concluding, he has justified that in the psychical fight among the three provinces, the final victory is snatched by id when the passionate lover satisfies his sexual desire and thus defeating ego and superego.

\section{Theoretical Framework}

This study aims to analyse the two dramas A Man for All Seasons and Murder in the Cathedral and the theoretical framework that is selected for this investigation is psychoanalysis theory. The structural model of personality presented by Sigmund Freud (1853-1939) in his psychoanalytical theory has been applied to the two works to present an analysis of the protagonists portrayed in the dramas. This personality theory explains the human behaviour from the perspective of the conscious part of the mind that has been controlled by three important provinces namely Id, ego and superego. Keeping these provisions of the conscious part of the mind into consideration for this study, this article brings the selected two drama under critical study to achieve the desired objectives. Moreover, some other theorist like Jung (2014) is considered secondarily for the conceptual references and grading of the personalities of characters.

\section{Research Methodology}

The current study is qualitative in its nature. Two dramas by two different writers collected have been selected for analysis. The dramas have been analysed within the framework of psychoanalysis. Because of their resemblance and proximity to each other, they are selected as data for the current study. It is a comparative study of the modern literary works through contemporary critical theories. Being a qualitative study in nature, we have relied on secondary data which includes texts from the selected dramas as well as critical commentaries on/about the dramas or other related works. The texts selected for analysis are A Man for All Seasons by Robert Bolt and Murder in the Cathedral by Tennyson Stern Eliot.

\section{Textual Analysis}

The protagonists of both the plays are respected and appreciated generally by the people for their commitment to Christianity and then later on death for the sake of religion in general and their principle in specific. In addition to their commitment and devotion to the religion and principles, they are equally applauded for being martyrs and their martyrdom is highlighted in the words of appreciation without peeping into their mottos and purposes. Because each 
action of an individual is ruled consciously or unconsciously by a specific motto and because that subdue the way in either direction. Moving logically into psychological terminologies, the dreams are the projections of our daily thinking and activities (Freud, 1970). Analysing the motto behind the dream of martyrdom of both the protagonists of the selected plays will bring us to the conclusion of titling their death either martyrdom or suicide. Close textual analysis is taken into consideration to reach to the characters' minds for knowing the psychic provinces that rule their personalities.

Thomas More, being good and ideal friend of Henry VIII, prefers religion and his principle of being committed to God when he comes into conflict with the King. Using his rationality and pragmatic understanding, he refuses to compromise on Christian Law to be used illegally for individual benefits by the King while getting married to the brother's wife Anne Boleyn. Religion comes first and then comes the obedience of the king because "no man can serve two masters" at a time. Considering it disobedience to God in specific and religion in general to surrender to the demands and ill intentions of the King while allowing him for the marriage, offers a religiously inflexible obedience to the King to assure his religious commitment to God when he presents his hand to the King to saw it from his body after the King visits to Chelsea for asking permission for marriage. However, considering him a pragmatist, he becomes a nonconformist to the King's demands without thinking about the consequences and confirms to God because he knows that God sends to paradise when one stands for Him (Bolt, 1969: 73).

Despite the different ways used by the King to compel him for the permission to give, he stands fast till he was crucified and that is the reason he becomes the hero of the "self" (Bolt, 1969: 90). Going deep into the past social life, Thomas More has been such a fair judge in his time of jurisdiction while deciding cases that Norfolk declares him "the only judge since Cato who did not accept bribes" (Bolt, 1969:58). His spotless tenure of serving as a chancellor and member of the court proves him a man of principles and follower of "Jungian self" what Emerson (1990) analogy terms as "non-conformist" which advocates his staunch beliefs in his religion because he thinks that "He made man to serve him wittily, in the tangle of his mind" (Bolt, 1969: 72).

In Freudian terminology, his unconscious that is stock of instinct uncensored desires clicks his conscious to compromise on his religion and principle for seeking worldly pleasure, but it is censored at the reception room by ego in specific and superego in general to act according to the reality principle of the religion and society. Thus, his personality gets dominated by the ego and he behaves in a psychologically healthy way while preferring religion in general and morality principle in specific. He tries to reconcile the irrational and bind claims of the id with the realistic demands of the external world (Feist et al., 2006). Id, in the form of different temptation of seeking worldly pleasure made by different characters, tries to dominate the psyche of Thomas More but the Id pleasure desires are blocked by the guard standing at the doorway of the ego and censored in the form of rejection of the temptation by Thomas More. Thus, is seeking the reality principle while completing his "Jungian self" and obeying God as Chapuys said and I quote:

"Thomas More is a true son of God" (Bolt, 1969: 22).

The introvert More turns inwardly to his own "Jungian self" with his individualized perceptions of the matter and clashes with the king and utilizes his psychic energy while 
looking at the matter with his own subjective view. Displaying his introverted attitude, he becomes conscious of the Id temptations made by the external world of different characters that try to corrupt the internal rational world of ego and superego. As a masochist and a nonconformist, he is happy in bearing the harsh consequences that his ego and superego bring for him after blocking the Id temptation because he considers worshipping God and obeying morality principle as the aim and purpose of one's life.

As an introvert person, Thomas More considers it more important to follow the inner "self" and highlights the idea that following the self and obeying the religion is what not to be considered as act of heroism or should not be tagged with the title of idealism. Because this act of giving importance to the "self' in general and religion in specific makes you a different human being and leads you to the stage what Carl Jung calls "self-completion or perfection". Miller (1953) (quoted in Kincaid's Guide: A Man for All Seasons, 1990) talked and I quote that being hero is nobody intention but, in every man, there is something like a core, an identity, a self that he cannot give up to remain himself. As a humanist and a government servant, Thomas More gives importance to the worldly affairs but he is more drawn by his religious life that he cannot give up for the temporary pleasure and that is where he finds his core, his identity and self (Kincaid, 1990). Being servant to his conscience in general and self in specific that compel him to obey God makes Thomas More a different Christian man than rest of the characters portrayed in A Man for All Seasons.

Not only the government official and social friends but his own wife personifies his staunch belief in God and importance of the Church in his social, personal and religious life when she was sent to visit him in prison, hoping to get a sign on the oath of supremacy of the king over the church while tempting him with king's favour but she fails to corrupt him with her temptations (Kincaid, 1990). His private conscience that is censored by the reality principle in his ego and superego is in clash with state that is trying to tempt his Id which is working to fulfil the pleasure principle by entering to the conscious part of More's mind. But Thomas More keeps a balance between the three differences provinces of mind to act rationally and accordingly while giving importance to his introvert thoughts and beliefs.

Although he remained in the company of royalty, but his "self" was drawn more by his monastic life. He did not affect his principled nature with the luxurious company of the king rather his conservation with the king and queen used be of academic nature. As member of Henry's council in 1518, Thomas More used to nourish the gathering with his scholarly thoughts about different disciplines like astronomy, geometry and theology (Kincaid, 1990). $\mathrm{He}$ remains in his monastic circle even in the company of the royalty personnel. He is inflexible religiously, steadfast morally and remains a man of principle socially. Steven D. Greydanus writes, and I quote that Thomas More in A Man for All Seasons is a man of virtue and principle whose priority is to stay alive without violating his conscience and thus is a pragmatic man who prefers Church over the state and worldly luxury at the cost of his sufferings in the start of the clash with the king and finally death at the end of the plot.

Acting pragmatically, Thomas More does not prefer death because he knows seeking for death is sin rather it is his conscience that compels him to obey God and disagree with the king's illegal demand that results in his death. It is not his pride or any other appetite that cause his death (Bolt, 1969: 32). Being a true Christian in beliefs and a man of principle in nature, Thomas More suffers with mental tortures at first and finally puts him to death. Even the 
invited death cannot shatter his beliefs when he is finally crucified and welcome the executor with the faith that God never refuses to accept His followers (Bolt, 1969: 58). The sanctity and integrity of Thomas More is not highlighted by Robert Bolt in his play only but the scholars like Christopher Hollis speaks about his holiness of the personality along with his other abilities in his research article Saint Thomas More, European. In the article, Hollis says, and we quote:

"The portrait of the sentimental liberal, three hundred years before his time but not quite possessed of the courage of his convictions. It must be frankly confessed, made it harder and not easier for Englishmen to recognize the true features of the sanctity of Thomas More" (Starkey, 2011: 35).

It is very vivid and crystal clear that a person who is going against the set traditions and customs must have a sound consciousness about understanding the very essence of his beliefs. To become a nonconformist in Emerson terminology, it is very necessary to know the rationale part of the Jungian self that forces oneself to challenge the ongoing waves that engrave the psyche of "yes men." A complete Jungian self-traces its roots in strong introversion attitude towards the rationality of different matters. Thomas More finds it preferable to be a nonconformist to the illogical, irrational and unreligious demands of Henry VIII so that to meet his Jungian self. He made a clear distinction between his introversion thoughts and extraversion attitude of the "yes men" to the king. The injunctions of the Church are kept at the doorway of his conscious mind while stopping the devalued and worldly wishes from the unconscious part of his mind. That is the reason that he finds it very difficult to surrender to the pleasure-seeking wishes of the Id and thus becomes rational towards the problem that apparently looks like an act of heroism.

Dealing with the clash between the church and the king supremacy in general and his principles and King's demands in particular, he respects his self and remains conscious of the Christian injunctions and thus making him "a man with an adamantine sense of his own self". All the characters in the play grasp hand of the king because one way or the other way they are in the grip of their Id to move its uncensored worldly wishes up to the rational conscious part of the mind without being censored by ego and superego. Thomas More presents his discrete loyalty to the king while serving him better before the clash they have but he finds it rightful to serve God and Church when it comes to the matter of serving two masters at a time which is advocated by the Chapuys in the play when he confirms to Steward by quoting More's words that "no man can serve two masters" at a time Starkey (2011) writes about the feelings of Thomas More about the newly coronated king Henry in his book Crown and Country that:

"Thomas More, the great scholar and lawyer, whose life and death were to be inextricably linked with Henry's. 'This day', he wrote of the new king's coronation, is the end of our slavery, the fount of liberty, the end of sadness and the beginning of joy" (Starkey, 2011: 279).

In the play Murder in the Cathedral by T.S Eliot, different characters also talk about the proud nature of Thomas Becket. When he comes back after exile, the messenger clearly says a dialogue about the pride of the Thomas Becket. He says and I quote: 
"You are right to express a certain incredulity.

He comes in pride and sorrow, affirming all his claims,

Assured, beyond doubt, of the devotion of the people,

Who receive him with scenes of frenzied enthusiasm,

Lining the road and throwing down their capes,

Strewing the way with their leaves and late flowers of the seasons"

(Eliot, 1935: 24).

Indicating the adverse consequence of his proud nature that are taking its decision from the very Id, the first priest talks about the nature of Thomas Becket that "I know that the pride bred of sudden prosperity/Was but confirmed by bitter adversity" (Eliot, 1935: 57). Here the priest is using two words "pride" and "prosperity" which indicate that pride is there in the personality of Thomas Becket and secondly this pride has been emerged due to the well luxurious and prosperous past life of Becket with the king. Because humbleness never gives rise to pride it is the luxuries that soil the seed of pride and develops in the form of a proud man. And here the priest also says that pride is in the character of Thomas Becket. Not only has the priest but the tempter also talked the same about him. He also says that Thomas Becket's lordship is too proud. Quoting him, he says that "If you go so fast, others may go faster/Your Lordship is too proud!" (Eliot, 1935: 40). Social life of Thomas Becket is exposed by characters like the tempter when he further takes us back to the past life of Thomas Becket when he was the Lord Chancellor. The unequal treatment and unfair dealing with different cases of various culprits is what exposed by the tempter when he says that "you were not used to be so hard upon the sinners/when they were your friends. Be easy man!" (Eliot, 1935: 80).

It lies very far from rational understanding that a religious person can be friend of sinners and most important than that he can favour them while deciding cases in their favour. Secondly, the tempter speaks in the same way right after this dialogue and again takes us to the past life of Thomas Becket. He says "I leave you to the pleasures of your high vices" where the phrase "high vices" undoubtedly refers to the socially luxurious life of Thomas Becket with the king. Secondly, he is using "vices" in the phrase which indirectly clicks our sense of understanding regarding the sin of pride of Thomas Becket which is among the seven deadly sins in Christianity. Additionally, the tempter knows the nature of Becket that he is thirsty for glory and pride that is why he is tempting Thomas Becket with his own tools of destruction that are confessed by Becket himself when he says is favour of the tempter thoughts. These words by tempter clearly indicate that Thomas Becket is hungry for pride. It shows that he is not only longing to be a famous and glorious man in his life, but he also wants to be a famous and pride man in Christianity after his death. He says to Becket:

"Save what you know already, ask nothing of me.

But think, Thomas, think of glory after death.

And think of your enemies, in another place" (98).

Moreover, Thomas Becket has a glorious past life in the company of king. He ate, drank and enjoyed in the majesty of the king. He used the company of the king and name of Christianity to get worldly pride and to gain popularity among the people. He is not the true follower of Christianity and is not the true son of God. He confesses this fact himself when he says: 
"While I ate out of the king's dish/to become servant of God was never my wish" (98).

In the dialogue, he himself confesses that to become the servant of God and to serve the religion and indirectly people was not his wish. He indirectly communicates with the reader that they are mistaken if they think that he is a servant of God. He says that he ate from the dishes of the king not for the purpose to preach God's words and become the servant of God and to get a religious place like saint in the society, but he ate to get a pride in the society. He, in a way, was making his way towards his popularity by using the company of the king. Different characters of the play highlight the extraversion personality of Thomas Becket and his irreligious identity. They all agree at the same truth that Thomas Becket carries a tragic flaw in the form of pride in his character and declare that he is going towards his death.

Being in the company of king, Thomas Becket has developed a germ for power in his personality. This germ for power causes his destruction after when he comes on bad terms with king. And Conroy D. Guyer talks about him that "pride" is the tragic flaw in the character of the protagonist of Eliot (1935) and then this tragic flaw is objectified by Thomas Becket in the form of his martyrdom and his martyrdom occurs incidentally because he does not wish for martyrdom being victim of worldly pleasure.

To serve God and to die for religion is not the aim of Thomas Becket's motivation for death. His aim of martyrdom is to get the crown of popularity and pride. He tries to blackmail his people emotionally by using religion. Though martyrdom is considered good if the cause and aims are fair, but Thomas Becket aim is totally worldly. Thomas Becket, out of pride and glory, wishes for martyrdom. Spender (1975) writes that:

"The hero or the martyr may be acting out of pride and the desire for glory. Although glory is indeed the crown of martyrdom, for the martyrdom to be martyred for this reason corrupts his action and puts him on the level of those concerned with their own power and glory" (194).

Thomas Becket's martyrdom is also corrupted by the desires for glory and power. Because his desire for martyrdom is to get glory and power and hence his selection is good but the way he uses is not fair. The will of Thomas Becket has to be observed within the objective will which is the love of God with such perfection that action becomes passive suffering, subjectively motiveless. He has a motive in his will, he must get glory and pride which is the true echo of his nature.

In addition to them, Francis Fergusson talks about Thomas Becket in quite the same way. Fergusson talks about Becket after the analysis of the dialogues by Becket and the fourth Tempter. Fergusson writes that:

"But the fourth Tempter offers Thomas the same formula (you know and do not know what it is to act or suffer) which Thomas had himself offered the women when he first appeared; and he shows Thomas that his act suffered progress toward martyrdom is motivated by pride and aims at general grasp of spiritual power" (224). 
Fergusson also talks about Thomas Becket by criticizing his motivation for martyrdom. Fergusson writes that Thomas Becket, no doubt, wishes for a perfect thing that is martyrdom but the aim and purpose of his getting such martyrdom is not right. He does not wish for martyrdom out of God's will rather his wish for martyrdom is out of pride and motivations for glory. He wishes for martyrdom not for that he is too much engrossed in the will of God rather he wishes for it because of his motivation for pride and glory.

In nutshell, the death of Thomas More is more glorified and has greater influential than that of Thomas Becket. The intentions and aims of Thomas More speak for the rightness of his martyrdom. He surrenders himself to the will of God right from the start of the play till the end. He practises his own principles and serves God from the start of his past till the present. Thomas Becket's death is the outcome of his pleasure-seeking desire. His aims of getting martyrdom are not the same as Thomas More. He wishes for martyrdom for getting glory and pride through this. His aims and purposes for martyrdom are not spiritual rather worldly. It is a tragic flaw of pride in his nature that causes his death incidentally, that is generally appreciated as martyrdom.

\section{Conclusion}

Both of the writers have tried to create religiously good, morally sound and psychologically healthy protagonists in their dramas but Bolt's (1969) approach towards drawing the personality of his hero in the drama A Man for All Seasons is more rational than the Thomas Stern Eliot's ability of producing socially reserved, personally introversive and rationally good character in his drama Murder in the Cathedral. Along with that, the writers have spent psychic energy to present their heroes with the intention of earning the favour of the readers while owing the sympathies of the readers by pushing their protagonists to face death at the end of the dramas. The writers have used their ability to mould the plot in such a way that the deaths of their protagonists seem socially appealing, morally sound and religiously acceptable.

Robert Bolt turns to be very skilful when his hero is brought into comparison with the protagonist of Thomas Stern Eliot because Bolt's More remains flat and sound character who is predictable and introversive in his attitude towards his actions regarding religion, society and matrimonial life. While Eliot's Becket is round and floating character who decides according to the demands of the time and keeping in mind the wishes of the people and thus turns to be extroversive in his attitude towards rationality at times. Therefore, the comparative analysis of the personality traits, that comprise three provinces id, ego and superego present in the conscious and unconscious part of human psyche, of both the characters brings us to the conclusive discussion that proves the researcher stance by highlighting the death of Thomas More as martyrdom and demarking the death of Thomas Becket as suicidal act.

The plays studied in this research carry historical inferences that are presented fictitiously by the writers. These plays are open to be studied from the historical point of view while criticizing the fictitious representation of the history. Both these plays are tragic in nature so the plays can be taken for a comparative study while keenly observing the basics of the modern tragedy. Hence this study recommends the plays for further research by scholars to be studied from the angels suggested. 


\section{References}

Assad, S. N. (2016). A postcolonial and psychoanalytical approach to The Heart of Darkness. Master thesis, Lulea University of Technology. https://www.divaportal.org/smash/record.jsf?pid=diva2\%3A1017029\&dswid=1634

Barfi, Z., Azizmohammadi, F., \& Kohzadi, H. (2013). A study of Kafka's the metamorphosis in the light of Freudian psychological theory. Research Journal of Recent Sciences, 2(10), 107-109. http://www.isca.in/rjrs/archive/v2/i10/16.ISCA-RJRS-2013-202.pdf

Barry, P. (2020). Beginning theory: an introduction to literary and cultural theory. Manchester University.

Bolt, R. (1969). A man for all seasons. Heinemann Educational Publishers Halley Court.

Cowlin, J. (2011). Why Do Things Fall Apart: A Psychological Analysis of Okonkwo's Personality and His Ultimate Demise in Chinua Achebe's Novel Things Fall Apart. Unpublished Thesis. http://www.divaportal.org/smash/get/diva2:403307/FULLTEXT01.pdf

Craib, I. (2001). Psychoanalysis: A critical introduction. Cambridge. Polity Press in Association.

Dobie, A. B. (2012). Theory into practice: An Introduction to Literary Criticism. Michael Rosenberg.

Emerson, R. W. (1990). Representative Men. Philips, Samson and Company.

Eliot, T. S. (1935). Murder in the Cathedral. Faber and Faber Publication.

Safran, J. D., \& Hunter, J. (2020). Psychoanalysis and psychoanalytic therapies. American Psychological Association.

Schultz, D. P., \& Schultz, S. E. (2016). Theories of personality. Cengage Learning.

Freud, A. (1966). The Ego and the Mechanisms of Defence. London International.

Freud, S. (1962). The Ego and the Id. New York: Norton, Print.

Freud, S. (1970). Introductory lectures on Psychoanalysis. Trans. Joan Riviere. London Heron Books.

Gardner, H. (1949). The Art of T S. Eliot. London: The Cresset P.

Gholipour, A. M., \& Sanahmadi, B. M. (2013). A psychoanalytic attitude to The Great Gatsby. International Journal of Humanities and Management Sciences (IJHMS), 1(1), 5153. http://www.isaet.org/images/extraimages/IJHMS\%200101213.pdf

Thorp, W. (1965). Howarth, Herbert. Notes on Some Figures Behind TS Eliot (Book Review). Comparative Literature, 17(3) 275-278. https://doi.org/10.2307/1769838

Jones, E. (1922). A psycho-analytic study of Hamlet. International psycho-analytical Press.

Liu, Y., \& Wang, C. (2011). Oedipus complex in literature works. Journal of Language Teaching and Research, 2(6), 1420-1424. https://doi.org/10.4304/jltr.2.6.1420-1424

Lynn, S. (1998). Texts and Contexts: Writing about Literature with Critical Theory. Longman Print.

Marry, S. P. U. (2013). Relocating the Soul in Paulo Coelho's Novel The Devil And Miss Prym. Research Journal of English Language and Literature, 42-45. http://rjelal.com/RJELAL\%201.2/RJELAL\%201.2.\%20pp\%2042-45.pdf

Mushtaq, H. (2010). The Triumph of ID Over Ego and Superego into His Coy Mistress. IJAR Journal of Language and Literature, 2, 8-13. https://papers.ssrn.com/sol3/papers.cfm?abstract_id=1628274

Rashid, A. A. (2013). When Frederic Henry is Disillusioned about his Identity: Alienation in a Farewell to Arms: A Critical Analysis. IOSR Journal of Humanities and Social Science, 16, 117-127. https://www.readcube.com/articles/10.9790/0837-164117127 
Jung, C. G. (2014). The development of personality. Routledge.

Manggala, G. (2007). Coleridge's sexual desire in the Poemkubla Khan (Doctoral dissertation, Universitas Airlangga). https://www.gesangunair.files.wordpress.com/2011/07/coleridge_s-sexual-desire-inthe-poem-kubla-khan.pdf psychoanalysis of kublakhan.pdf

Hossain, M. M. (2017). Psychoanalytic theory used in English literature: A descriptive study. Global Journal of Human-Social Science: Linguistics and Education, 17(1), 41-46. https://globaljournals.org/GJHSS_Volume17/3-Psychoanalytic-Theory-used.pdf

Miller, H. C. (1997). The Complete works of Sir Thomas More. Yale University

Ryan, M. (2007). Literary Theory: A Practical Introduction. Blackwell Print.

Skinner, B. F. (1953). Science and Human Behaviour. Macmillan.

Spender, S. (1975). Eliot. Modern masters' series.

Starkey, D. (2011). Crown and Country: The Kings and Queens of England. Harper Press.

Tiffin, H. (1987). Post-colonial literatures and counter-discourse. Kunapipi, 9(3), 17-34. https://ro.uow.edu.au/kunapipi/vol9/iss3/4/

Wadsworth, T. (2003). Introduction to Psychology. Blackwell Publishers. 